\title{
Elsinoë australis Causing Spot Anthracnose on Poplar in China
}

\author{
Lijuan Zhao, Hongju Xiao, Xujie Ma, and Qiang Cheng ${ }^{\dagger}$ \\ Key Laboratory of Forest Genetics \& Biotechnology of Ministry of Education, Co-Innovation Center for Sustainable Forestry in \\ Southern China, Nanjing Forestry University, Nanjing 210037, China
}

\begin{abstract}
Poplar plantations provide important industrial feedstock in China. Red spot symptoms were observed on leaves of Populus tomentosa and P. deltoides in southeastern China. Based on morphology and molecular phylogenetic analysis, the fungus isolated from disease spots was identified as Elsinoe australis, which has been previously recognized as a pathogen of Citrus spp. and jojoba but has not been reported in China. Pathogenicity tests found that isolates from two poplar species caused red spot symptoms on leaves from

MAT1-1 and MAT1-2 loci of E. australis was revealed by genome sequence and long-range PCR analyses. Single isolates carried only one of two opposite mating-types was confirmed by idiomorph-specific PCR, suggesting a heterothallic mating system. Our results not only revealed a new E. australis pathotype causing poplar spot anthracnose in China but also provided its genome and mating system information.
\end{abstract} different poplar species and also led to scab formation on the fruit of one hybrid citrus but not on fruit of orange, lemon, or grapefruit. The draft genome of one E. australis isolate was generated. The genetic architecture of the
Keywords: Elsinoё australis, molecular phylogeny, pathogenicity, genome, mating type locus
Elsinoë australis (anamorph: Sphaceloma australis), a fungus in the order Myriangiales, is a well-known pathogen of Citrus spp. that generally infects the fruit of most sweet orange (Citrus sinensis). Under wet conditions such as rain, dew or irrigation, E. australis conidia infect young fruit and lead to raised and corky lesions (scab pustules). The fruit having such scabs are misshapen and subject to premature drop, resulting in significant quality and yield losses in epidemic regions (Timmer et al. 2000). The original pathotype of E. australis, sweet orange scab (SOS), was reported in South America (Bitancourt and Jenkins 1937). E. australis had been a restricted pathogen, because for the last century, it had only been reported occurring in Brazil, Argentina, and Paraguay in South America. It affected sweet orange and some mandarin (C. reticulata) cultivars, and infected fruit but not other organs (Chung 2011). E. australis (SOS pathotype) is listed as a quarantine pest in many countries, such as the European Union, and is subjected to phytosanitary controls (EFSA Panel on Plant Health (PLH) et al. 2017).

In recent years, continuous reports of new E. australis pathotypes have indicated an expansion of its epidemic region as well as its host range and affected organs. The Natsudaidai pathotype was identified by Hyun et al. (2001) in South Korea, and it specifically infects fruit of $C$. natsudaidai but not sweet orange. A Natsudaidai-like pathotype that can infect both fruit and leaves of multiple Citrus spp., including grapefruit, sweet orange, and tangerine, was found in Texas, United States (Kunta et al. 2013). Additionally, the finger lime (FL) and jojoba black scab (JBS) pathotypes that colonize finger lime (C. australasica) and jojoba (Simmondsia chinensis), respectively, were reported in Australia (Ash et al. 2012; Miles et al. 2015). To date, the hosts of E. australis have been restricted to Citrus spp. and S. chinensis,

${ }^{\dagger}$ Corresponding author: Q. Cheng; chengqiang@njfu.edu.cn

Funding: This work was supported by the National Natural Science Foundation of China (grant numbers 31870658 and 31570639), the Distinguished Young Scholars Fund of Nanjing Forestry University, the Priority Academic Program Development of Jiangsu Higher Education Institutions, and Postgraduate Research \& Practice Innovation Program of Jiangsu Province.

The author(s) declare no conflict of interest.

Accepted for publication 18 February 2020.

(C) 2020 The American Phytopathological Society and the distribution of this fungus is mainly limited to several countries of South America, Korea, Japan, Australia, and the United States (https://www.cabi.org/isc/datasheet/20774), and there are no reports of $E$. australis infecting poplar trees and existing in China.

Poplar trees (Populus spp.), with impressive growth performance and high productivity levels, are widely cultivated worldwide. The genus Populus comprises six taxonomically distinct sections: Abaso, Turanga, Leucoides, Aigeiros, Tacamahaca, and Leuce. Intrasectional hybridization is common in Populus spp., but only the section Leuce has strong intersectional incompatibility barriers with the others, indicating a major division (Cronk 2005). In China, poplar plantations encompass more than 7 million ha, in that many consist of superior clonal poplar from Aigeiros and Leuce (Fang 2008). Poplar plantations provide important feedstock for producing fiberboard, paper pulp, and building timber, as well as forming shelterbelts against deserts and wind (Bradshaw et al. 2000). Poplars are susceptible to many pathogens in nature, this is especially true on plantations with a monoclonal culture (Duplessis et al. 2009). For example, E. populi colonizes poplar leaves of Populus nigra, P. euramericana, and $P$. deltoides, causing poplar spot anthracnose (PSA) in South America, Europe, and Australia (http://www.herbimi. info/herbimi/results.htm?name=Elsinoe\%20populi) (Jenkins 1932; Saccardo 1878). E. populi was redescribed, and its phylogenetic sequences were generated in a recent systematic study on Elsino spp. (Fan et al. 2017).

Here, we report the identification of a new E. australis pathotype that causes PSA in China and we test its pathogenicity on diverse poplar and citrus species. We also report a draft genome of this pathogen and reveal the genetic structure of opposite mating loci in different isolates. The results expand our knowledge of the host, location, genome, and mating system of E. australis, which will facilitate studies of this multihost pathogen.

\section{Materials and Methods}

Isolation and morphological observation. Five leaves with red lesions were collected from one $P$. tomentosa and one $P$. deltoides from parks at Nanjing and Wuhu in southeastern China, respectively, in September 2016 and September 2017, respectively. The leaves were cut into approximately 5-mm segments, surface disinfested in $0.1 \%$ mercuric chloride, and washed in sterile distilled water. After drying, the segments were placed on potato dextrose agar (PDA) and incubated at $25^{\circ} \mathrm{C}$. Some slow-growing colonies emerged from lesions after 2 weeks. Conidia were prepared using the rain water 
shaking method, as described previously (Hyun et al. 2015). In brief, 3 -week-old colonies on PDA were cut into $0.5-\mathrm{cm}$ patches, then grown in $50 \mathrm{ml}$ of sterile rain water at $25^{\circ} \mathrm{C}$ at $180 \mathrm{rpm}$ for $24 \mathrm{~h}$ in a shaking incubator. Conidia were collected by filtration through nylon mesh and centrifugation. The sizes of the conidia and conidiogenous cells were measured under a Zeiss Axio Scope A1 microscope at $\times 1,000$ magnification. For morphological observation of colonies, one $0.5-\mathrm{cm}$ patch was grown in the center of a 6 -cm petri dish containing PDA for 4 weeks.

DNA extraction, PCR amplification, and sequencing. Mycelia were harvested from plates, and genomic DNA was extracted and purified using a DNAsecure Plant Kit (Tiangen, Beijing, China). DNA was quantified with agarose gel electrophoresis and the ND 1000 Nanodrop spectrophotometer (NanoDrop Technologies, Wilmington, DE, U.S.A.). The internal transcribed spacer (ITS) region was amplified with the primers ITS1 (5'-TCCGTAGGTGAACCTGCGG-3') and ITS4 (5'TCCTCCGCTTATTGATATGC-3') (White et al. 1990), and the translation elongation factor 1- $\alpha(T E F 1-\alpha)$ gene was amplified with the primers elongation-1-F (5'-AGCCCCTCCGTCTTCCTCTCCAG-3') and elongation-1-R (5'-CGGTACGGCGGTCAATCTTCTCG-3') (Hyun et al. 2009). PCR was performed using KOD-plus-Neo DNA polymerase (Toyobo, Osaka, Japan). The amplified products for each gene were separated by agarose electrophoresis and ligated into the pEASY-Blunt Zero vector (Beijing TransGen Biotech Co., Ltd.) for Sanger sequencing (Genewiz, Suzhou, China).

Phylogenetic analysis. The phylogenetic analysis included ITS and TEF 1- $\alpha$ sequences of 8 isolates (NL1, NL2 and WH-1 to WH-6) collected in this study, 20 E. australis isolates (Ash et al. 2012; Kunta et al. 2013; Miles et al. 2015), 3 Elsinoë fawcettii isolates associated with citrus (Miles et al. 2015), 2 E. populi isolates associated with poplar, and 1 Myriangium hispanicum isolate belonging to the order Myriangiales as the out-group (Table 1). The concatenated DNA sequences of ITS and TEF1$\alpha$ were used to construct the phylogenetic tree. Alignments were performed using ClustalW (Thompson et al. 1994). A maximum-likelihood tree was constructed using MEGA 7.0 (Kumar et al. 2016). Phylogenies were constructed following the Tamura-Nei model (Tamura and Nei 1993). All positions containing gaps were excluded from the analysis. The bootstrap consensus tree was inferred from 1,000 trees.

Pathogenicity. Seedlings of Citrus spp., including $C$. sinensis, $C$. natsudaidai, and C. reticulata, and fruit of $C$. unshiu, $C$. sinensis, $C$. paradise, C. limon, and C. $\times$ reticulata 'Ehime 38 ' were purchased

Table 1. Strains of Elsinoë spp. isolates used in this study, with collection details, GenBank accession numbers, E-values, and identities ${ }^{\mathrm{a}}$

\begin{tabular}{|c|c|c|c|c|c|c|c|c|c|}
\hline \multirow[b]{2}{*}{ Species } & \multirow[b]{2}{*}{ Isolate } & \multirow[b]{2}{*}{ Host } & \multirow[b]{2}{*}{ Locality } & \multicolumn{2}{|c|}{$\begin{array}{c}\text { GenBank accession } \\
\text { number }\end{array}$} & \multicolumn{2}{|c|}{ ITS } & \multicolumn{2}{|l|}{$T E F-1 \alpha$} \\
\hline & & & & ITS & $T E F-1 \alpha$ & E value & Identity (\%) & E value & Identity $(\%)$ \\
\hline $\begin{array}{l}\text { Elsinoë } \\
\text { australis }\end{array}$ & NL1 & $\begin{array}{l}\text { Populus } \\
\text { tomentosa }\end{array}$ & China & MN217577 & MN227160 & $1.00 \mathrm{E}-138$ & 100.00 & $2.00 \mathrm{E}-175-3.00 \mathrm{E}-173$ & $99.70-100.00$ \\
\hline E. australis & NL2 & P. tomentosa & China & MN217578 & MN227161 & $1.00 \mathrm{E}-138$ & 100.00 & $2.00 \mathrm{E}-175-3.00 \mathrm{E}-173$ & $99.70-100.00$ \\
\hline E. australis & WH-1 & P. deltoides & China & MN217571 & MN227154 & $1.00 \mathrm{E}-138$ & 100.00 & $1.00 \mathrm{E}-173-3.00 \mathrm{E}-173$ & $99.70-100.00$ \\
\hline E. australis & WH-2 & P. deltoides & China & MN217572 & MN227155 & $1.00 \mathrm{E}-138$ & 100.00 & $8.00 \mathrm{E}-175-3.00 \mathrm{E}-173$ & 99.70 \\
\hline E. australis & WH-3 & P. deltoides & China & MN217573 & MN227156 & $1.00 \mathrm{E}-138$ & 100.00 & $8.00 \mathrm{E}-175-1.00 \mathrm{E}-173$ & $99.70-100.00$ \\
\hline E. australis & WH-4 & P. deltoides & China & MN217574 & MN227157 & $1.00 \mathrm{E}-138$ & 100.00 & $2.00 \mathrm{E}-175-1.00 \mathrm{E}-173$ & $99.70-100.00$ \\
\hline E. australis & WH-5 & P. deltoides & China & MN217575 & MN227158 & $1.00 \mathrm{E}-138$ & 100.00 & $2.00 \mathrm{E}-175-1.00 \mathrm{E}-173$ & $99.70-100.00$ \\
\hline E. australis & WH-6 & P. deltoides & China & MN217576 & MN227159 & $1.00 \mathrm{E}-138$ & 100.00 & $2.00 \mathrm{E}-175-3.00 \mathrm{E}-173$ & $99.70-100.00$ \\
\hline E. australis & $\mathrm{KNa}-5$ & $\begin{array}{l}\text { Citrus } \\
\quad \text { natsudaidai }\end{array}$ & Korea & FJ010328 & FJ010252 & $1.00 \mathrm{E}-138$ & 100.00 & $2.00 \mathrm{E}-175-3.00 \mathrm{E}-173$ & $99.70-100.00$ \\
\hline E. australis & $\mathrm{KNa}-1$ & C. natsudaidai & Korea & FJ010326 & FJ010250 & $1.00 \mathrm{E}-138$ & 100.00 & $2.00 \mathrm{E}-175-3.00 \mathrm{E}-173$ & $99.70-100.00$ \\
\hline E. australis & $\mathrm{Na}-2$ & C. natsudaidai & Korea & FJ010336 & FJ010260 & $1.00 \mathrm{E}-138$ & 100.00 & $2.00 \mathrm{E}-175-1.00 \mathrm{E}-173$ & $99.70-100.00$ \\
\hline E. australis & SOS54 & C. sinensis & United States & KC211040 & KC211051 & $1.00 \mathrm{E}-138$ & 100.00 & $2.00 \mathrm{E}-175-3.00 \mathrm{E}-173$ & $99.70-100.00$ \\
\hline E. australis & SOSL54 & C. sinensis & United States & KC211041 & KC211049 & $1.00 \mathrm{E}-138$ & 100.00 & $2.00 \mathrm{E}-175-3.00 \mathrm{E}-173$ & $99.70-100.00$ \\
\hline E. australis & S5174A & C. sinensis & United States & KC211042 & KC211053 & $1.00 \mathrm{E}-138$ & 100.00 & $2.00 \mathrm{E}-175-3.00 \mathrm{E}-173$ & $99.70-100.00$ \\
\hline E. australis & SOS61 & C. reticulata & United States & KC211033 & KC211047 & $1.00 \mathrm{E}-138$ & 100.00 & $1.00 \mathrm{E}-172-2.00 \mathrm{E}-170$ & $99.10-99.40$ \\
\hline E. australis & SOS47 & $\begin{array}{l}\text { Citrus } \times \text { paradisi } \\
\text { 'Rio Red' }\end{array}$ & United States & KC211039 & KC211050 & $1.00 \mathrm{E}-138$ & 100.00 & $1.00 \mathrm{E}-172-2.00 \mathrm{E}-170$ & $99.10-99.40$ \\
\hline E. australis & Ea-1 & C. unshiu & Argentina & FJ010312 & FJ010236 & $5.00 \mathrm{E}-137$ & 99.62 & $6.00 \mathrm{E}-170-9.00 \mathrm{E}-168$ & 98.49-98.80 \\
\hline E. australis & 70212 & C. unshiu & Argentina & FJ010291 & FJ010215 & $5.00 \mathrm{E}-137$ & 99.62 & $3.00 \mathrm{E}-168-1.00 \mathrm{E}-166$ & $98.19-98.50$ \\
\hline E. australis & CBS 230.64 & C. aurantium & Argentina & KX887197 & KX886843 & $5.00 \mathrm{E}-137$ & 99.62 & $3.00 \mathrm{E}-168-1.00 \mathrm{E}-166$ & $98.19-98.50$ \\
\hline E. australis & CBS $314.32^{\mathrm{T}}$ & C. aurantium & Brazil & KX887198 & KX886844 & $5.00 \mathrm{E}-137$ & 99.62 & $3.00 \mathrm{E}-168-1.00 \mathrm{E}-166$ & $98.19-98.50$ \\
\hline E. australis & CBS 229.64 & C. aurantiifolia & Brazil & KX887196 & KX886842 & $5.00 \mathrm{E}-137$ & 99.62 & $3.00 \mathrm{E}-168-1.00 \mathrm{E}-166$ & $98.19-98.50$ \\
\hline E. australis & $\begin{array}{l}\text { FZ-STM- } \\
\text { CLB-1.4 }\end{array}$ & C. senensis & Brazil & FJ010318 & FJ010242 & $5.00 \mathrm{E}-137$ & 99.62 & $5.00 \mathrm{E}-171-2.00 \mathrm{E}-169$ & $98.80-99.10$ \\
\hline E. australis & VRG-BRT & C. senensis & Brazil & FJ010354 & FJ010284 & $5.00 \mathrm{E}-137$ & 99.62 & $3.00 \mathrm{E}-168-1.00 \mathrm{E}-166$ & $98.19-98.50$ \\
\hline E. australis & S5074A3 & C. paradisi & United States & KC211044 & KC211055 & $5.00 \mathrm{E}-137$ & 99.62 & $1.00 \mathrm{E}-172-2.00 \mathrm{E}-170$ & $99.10-99.40$ \\
\hline E. australis & S5074A1 & C. paradisi & United States & KC211045 & KC211056 & $5.00 \mathrm{E}-137$ & 99.62 & $1.00 \mathrm{E}-172-2.00 \mathrm{E}-170$ & $99.10-99.40$ \\
\hline E. australis & BRIP 54681 & S. chinensis & Australia & KF577778 & KF577781 & $5.00 \mathrm{E}-137$ & 99.62 & $1.00 \mathrm{E}-172-2.00 \mathrm{E}-170$ & $99.10-99.40$ \\
\hline E. australis & BRIP 54682 & S. chinensis & Australia & KF577779 & KF577782 & $5.00 \mathrm{E}-137$ & 99.62 & $1.00 \mathrm{E}-172-2.00 \mathrm{E}-170$ & $99.10-99.40$ \\
\hline E. australis & BRIP 52616 & C. astralasica & Australia & KF577777 & KF577780 & $8.00 \mathrm{E}-135$ & 99.25 & $1.00 \mathrm{E}-172-2.00 \mathrm{E}-170$ & $99.10-99.40$ \\
\hline E. fawcettii & Jin-6 & C. sunki & Korea & FJ010323 & FJ010247 & $2.00 \mathrm{E}-122$ & 95.88 & $5.00 \mathrm{E}-140-7.00 \mathrm{E}-138$ & $91.87-92.19$ \\
\hline E. fawcettii & DAR 70027 & C. limon & Australia & FJ010288 & FJ010212 & $2.00 \mathrm{E}-122$ & 95.88 & $5.00 \mathrm{E}-140-7.00 \mathrm{E}-138$ & $91.87-92.19$ \\
\hline E. fawcettii & CBS $139.25^{\mathrm{b}}$ & Citrus sp. & United States & KX887219 & KX886865 & $2.00 \mathrm{E}-122$ & 95.88 & $5.00 \mathrm{E}-140-7.00 \mathrm{E}-138$ & $91.87-92.19$ \\
\hline E. populi & CBS 289.64 & P. deltoides & Argentina & KX887273 & KX886918 & $1.00 \mathrm{E}-120$ & 95.51 & $2.00 \mathrm{E}-137-3.00 \mathrm{E}-135$ & $91.27-91.59$ \\
\hline E. populi & CBS 290.64 & P. deltoides & Argentina & KX887274 & KX886919 & $1.00 \mathrm{E}-120$ & 95.51 & $2.00 \mathrm{E}-137-3.00 \mathrm{E}-135$ & $91.27-91.59$ \\
\hline $\begin{array}{l}\text { Myriangium } \\
\text { hispanicum }\end{array}$ & CBS 247.33 & $\begin{array}{l}\text { Acer } \\
\quad \text { monspessulanum }\end{array}$ & N/A & KX887304 & KX886948 & $6.00 \mathrm{E}-92$ & 88.59 & 7.00E-106-9.00E-105 & $84.38-84.68$ \\
\hline
\end{tabular}

${ }^{a}$ E-values and identities derived from pairwise comparisons between internal transcribed spacer (ITS) and translation elongation factor $1 \alpha(T E F-1 \alpha)$ sequences of Elsinoë spp. and those of isolates in this study (marked in bold). Ranges are approximate. N/A = not available.

b The ex-type strain. 
from local markets. $P$. deltoides 'I-69', $P$. tomentosa, $P$. tremula $\times P$. tremuloides 'T89', and $P . \times$ euramericana 'Nanlin 895 ' were grown at the Nanjing Forestry University campus.

Detached leaves (young and light green) were disinfested in $0.5 \%$ hypochlorite sodium for $2 \mathrm{~min}$, followed by rinses in sterile distilled water (Timmer et al. 1996). Then, they were placed on water agar $(1.5 \%)$ in Petri dishes. On the abaxial side of the leaf, $10-\mu 1$ droplets of conidial suspension at $10^{6} / \mathrm{ml}$ were placed, and $10-\mu l$ droplets of sterile, deionized water were placed as the control. For isolates with few or no conidia, mycelial plugs were used, and sterile agar plugs were used as controls. The covered plates were sealed with Parafilm to avoid drying and incubated at $25^{\circ} \mathrm{C}$ with a 14-h photoperiod using white fluorescent bulbs (Mitsubishi FL40SS-W/37) producing 15,000 lux. After 14 days, the leaves were surface sterilized, and reisolation of the fungus was attempted to verify Koch's postulates. The fruit of citrus were surface sterilized, inoculated as described above, and placed on moist filter paper within a plastic chamber. Each isolate was inoculated on three leaves from one poplar and one citrus tree, and on three fruit. The conidia or mycelial plugs of WH-1, WH-2, WH-3, NL1, and NL2 were used for testing pathogenicity. Spot anthracnose symptoms on leaves and scab symptoms on fruit were recorded at 14 and 21 days postinoculation, respectively. The tissue culture seedlings of $P$. tomentosa transplanted in pots were used for pathogenicity tests of whole plants. A mycelian and conidial suspension was sprayed on seedlings, which were then covered with a glass beaker to maintain the humidity.

Genome sequencing, assembly, and annotation. The genome of E. australis NL1 was sequenced on an Illumina HiSeq 2500 platform using one paired-end library (Annoroad Gene Technology, Beijing, China). The raw reads were cleaned by removing the adapter sequences, low-quality sequences (more than $15 \%$ bases with a Phred Quality Score under 19), and any reads with more than 5\% unknown sequences, designated as "Ns". The cleaned reads were assembled using SOAPdenovo (Luo et al. 2012). The completeness assessment of the assembled genome was assessed using the BUSCO v3 against the fungi_odb9 dataset (Waterhouse et al. 2017). The genome annotation was performed with GeneMark-ES (Ter-Hovhannisyan et al. 2008) and FGENESH (Solovyev et al. 2006). Carbohydrate-active enzymes (CAZymes) were searched using dbCAN2 (Zhang et al. 2018). The secretory proteins were identified using SignalP4.1 (Petersen et al. 2011) and TMHMM (Krogh et al. 2001). Biosynthetic gene clusters were analyzed using antiSMASH 5.0 (Blin et al. 2019). Sequences of large fragments of clusters were aligned using Align-Water (EMBOSS; http://emboss.sourceforge.net/). SynMap from the web-based $\mathrm{CoGe}$ Comparative Genomics Platform (https://genomevolution.org/coge/) was used to generate a dot plot of the BlastN alignments for the visualization of synteny across whole genomes (Castillo et al. 2018).

Mating loci. The MAT1-1 locus was revealed by BLASTp and tBLASTn searches using a collection of representative mating proteins of Pezizomycotina as query sequences (Wilken et al. 2017). The MAT1-2 locus was amplified using primers designed based on the flanking genes encoding endonuclease DNA lyase (APN2) and phosphoinositide-binding domain protein $(P x)$, APN2-F $\left(5^{\prime}-\right.$ TTACTCTCCCATTTCCCCTCCTC-3') and Px-R (5'-ATTGTCAGT GCATGTTTCTCCCAT-3'), respectively. The idiomorph-specific primer pairs of MAT1-1-1 (5'-CATCTTCAAGTCCTTCCAGCAG-3' and 5'-GGAGTCGATAAAGGGGTATGGA-3') and MAT1-2-1 (5'CAGTCATCTTCTCTGCTTTCTTCTT- ${ }^{\prime}$ and $5^{\prime}$-TCTCAATACACTG TCTCATCCTCAC-3') were used for determining the mating types of the isolates.

Disease survey. The fungi were collected by cutting red lesions from poplar leaves. DNA samples of lesions were extracted as described above. One DNA sample from a poplar leaf without symptoms was chosen as the control. Diagnostic PCR was performed with MAT1-1-1 primers using KOD-plus-Neo DNA polymerase (Toyobo, Osaka, Japan).

\section{Results}

Pathogen isolation and morphological characterization. In September 2016 and 2017, similar spot anthracnose symptoms were observed on lower branch leaves of $P$. tomentosa and $P$. deltoides in
Nanjing and Wuhu, China. The symptoms were usually found on leaves on the lower part of a tree, occasionally found on the whole tree. Numerous leaf spots were 0.1 to $5 \mathrm{~mm}$ in diameter on $P$. tomentosa (Fig. 1A) and 0.3 to $15 \mathrm{~mm}$ in diameter on P. deltoides (Fig. 1B), rounded or irregular, often coalescing and light red to reddish black. Leaf spots were observed on both sides of the leaves, and severe symptoms were characterized by perforations, but no raised scab symptoms were observed on leaves.

Two isolates from $P$. tomentosa and six from $P$. deltoides were grown on PDA plates. The colonies differed in color, ranging from light red to dark brown. Generally, colonies were slow growing, averaging a approximately $31 \mathrm{~mm}(22.6$ to $37.2 \mathrm{~mm})$ in diameter after 4 weeks, and the colonies were raised, pulvinate, sulcate, stellated, gummy to mucoid, with a crenate margin and white to gray aerial mycelia (Fig. $1 \mathrm{C}$ to $\mathrm{J}$ ). Whiteside and rain water shaking methods were used for preparing conidia; however, only isolate $\mathrm{WH}-1$, prepared using the latter method, generated enough conidia for further analyses (Hyun et al. 2015; Whiteside 1978). The conidia of WH-1 were hyaline, aseptate, granular, ellipsoid to short cylindrical, apex obtuse, and 5.1 to $7.2 \times 2.3$ to $4.3 \mu \mathrm{m}$ (average $6.2 \times 3.2 \mu \mathrm{m}, n=50$ ) (Fig. $1 \mathrm{~K}$ ), and conidiophores were hyaline, verruculose, ampulliform to doliiform, and 7.2 to $16.1 \times$ 2.9 to $5.1 \mu \mathrm{m}$ (average $10.8 \times 3.9 \mu \mathrm{m}, n=30$ ) (Fig. $1 \mathrm{~L}$ ).

Molecular identification and phylogenetic analysis. The pairwise comparisons of ITS and TEF-1 $\alpha$ among the eight isolates showed an E-value of 1.00E-138 (identity of 100\%) and E-value $\leq 3.00 \mathrm{E}-173$ (identities of 99.7 to $100 \%$ ), respectively (Table 1). Using a BLASTn search, the best hits came from different strains of $E$. australis. For example, E-value of 1.00E-138 (identity of $100 \%$, ITS) and E-value $\leq 3.00 \mathrm{E}-173$ (identities of 99.7 to $100 \%, T E F-1 \alpha$ ) against $E$. australis $\mathrm{KNa}-5$ (Table 1) suggested that all of the isolates were species of $E$. australis.

The phylogenetic analysis further supported this inference. All of the isolates from poplar resided in a high bootstrap-supported (99\%) E. australis clade that was distinct from E. populi, E. fawcettii, and $M$. hispanicum (Fig. 2). The phylogenetic analysis revealed that the isolates from poplar were clustered with the Korean isolates of the Natsudaidai pathotype and some of the isolates of the U.S. Natsudaidai-like pathotype but were distinct from the Australia JBS and FL pathotypes' isolates, as well as the South America SOS pathotype's isolates (Fig. 2).

Pathogenicity. The pathogenic analysis on water agar using detached leaves of four species of poplar-Populus spp. of the section Aigeiros (P. deltoides and P. $\times$ euramericana) and Populus spp. of the section Leuce $(P$. tomentosa and $P$. tremula $\times P$. tremuloides $)$ showed that all of the tested isolates produced dark-red lesions that were similar to those observed in the field (Fig. 3A to E). Additionally, Koch's postulates were fulfilled by reisolating the same fungi from the lesions of inoculated leaves. Pathogenicity results using whole poplar plants were similar to those of the detached-leaf assays. However, in vitro inoculations of the leaves of $C$. sinensis, $C$. natsudaidai, and $C$. reticulata produced no observable symptoms, even when using young leaves (light green and 1/3 to $1 / 2$ expanded). For the detached-fruit assay, a range of fruit of Citrus spp. failed to produce scabs when inoculated with any isolate, except for the fruit of the Ehime 38 hybrid citrus, which was susceptible to all of the isolates (Fig. 3F).

The isolates from poplar seemed to have a different host range compared with the known pathotypes of E. australis. Consequently, we proposed that they represent a new pathotype, PSA. These isolates were deposited in the China Forestry Culture Collection Center (accession numbers CFCC 53944 to CFCC 53951), and the name and appropriate information for this species have submitted to MycoBank under accession number MB 832459.

Genome sequence resource. To provide a genetic resource for $E$. australis research, genome sequence assemblies were generated for NL1 (GenBank accession number NHZQ00000000.1). In total, more than 40.5 million paired-end reads and $6.2 \mathrm{~Gb}$ of raw data were obtained. In total, 98 scaffolds were assembled from $6.1 \mathrm{~Gb}$ of clean data. The largest scaffold was 1,881,367 bp, and the N50 value was $897,805 \mathrm{bp}$. More than $50 \%$ of the sequence was within nine 
scaffolds (L50). The draft genome of E. australis NL1 consists of $23.34 \mathrm{Mb}$, with a GC content of $52.7 \%$, and the coverage was estimated to be $265 x$ by comparing the total sequenced nucleotides to the assembled genome size. A comparison of the draft genome sequences to the 290 BUSCO fungal single-copy orthologs indicated that $97.9 \%$ of the genome was complete. In total, 9,223 proteincoding genes were predicted. Furthermore, an analysis of signal peptides revealed that 1,511 proteins, of which 629 lacked transmembrane helices, were considered to be secreted proteins. In addition, E. australis NL1 possesses 522 CAZymes, including 221 proteins with a predicted signal peptide (Table 2). Two type I polyketide synthases (T1PKS), 11 nonribosomal peptide synthases (NRPS) or NRPS-like, 6 terpene synthases, and 2 NRPS-T1PKS gene clusters were predicted. Among these, a conserved synteny for the
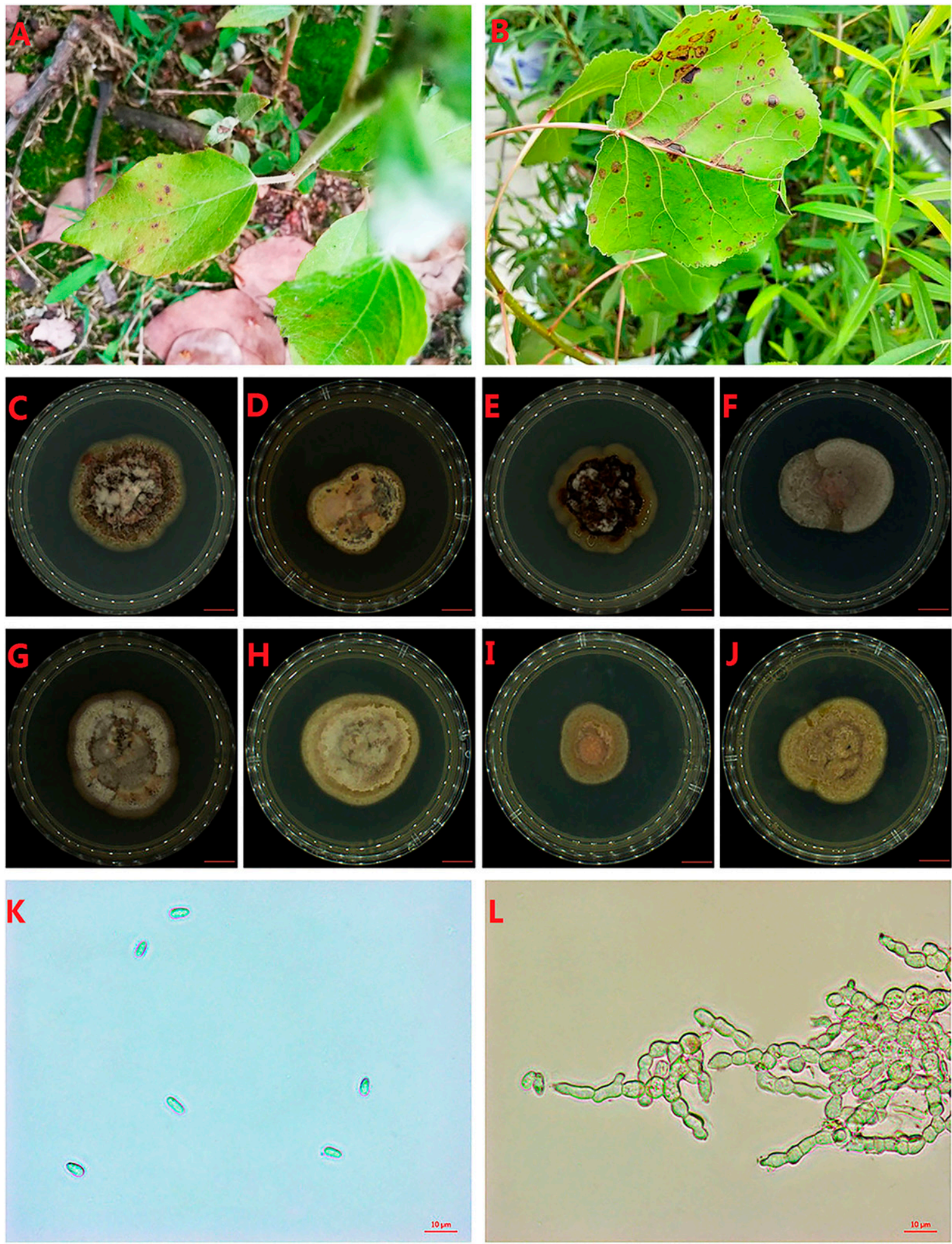

Fig. 1. Disease symptoms of Populus in the field and morphological characteristics of colonies, conidia, and conidiophores. A, Populus tomentosa and B, P. deltoides. C to J, Appearances of colonies of isolates WH-1 to WH-6, NL1, and NL2 on potato dextrose agar. Bars $=1 \mathrm{~cm}$. K, Conidia of WH-1 were hyaline, aseptate, and ellipsoid to short cylindrical. L, Conidiophores of WH-1 were hyaline, verruculose, and ampulliform to doliform. Bars $=10 \mu \mathrm{m}$. 
10-gene cluster that produces elsinochrome was observed between E. australis and E. fawcettii (Ebert et al. 2018).

One genome of E. australis Ea-1 belonging to the SOS pathotype was reported in December 2019 (Shanmugam et al. 2019). Ea-1 is $23.79 \mathrm{Mb}$ with a GC content of $52.6 \%$ and 9,002 protein-coding genes, which are close to those of NL1. The comparison of biosynthetic gene clusters between NL1 and Ea-1 showed that six clusters (three from NL1 and three from Ea-1) were distinct. However, alignments of the large fragments (21 to $45 \mathrm{~kb}$ ) of the distinct clusters to the opposite genome revealed that five clusters had highly identical sequences (70.1 to $96.1 \%$ ) and most of their differences occurred in intergenic regions. There was only one truly distinct cluster (NRPS, 1,272 to 46,677 nucleotides of scaffold 4 of Ea-1), of which three biosynthetic genes were absent in the NL1 genome.

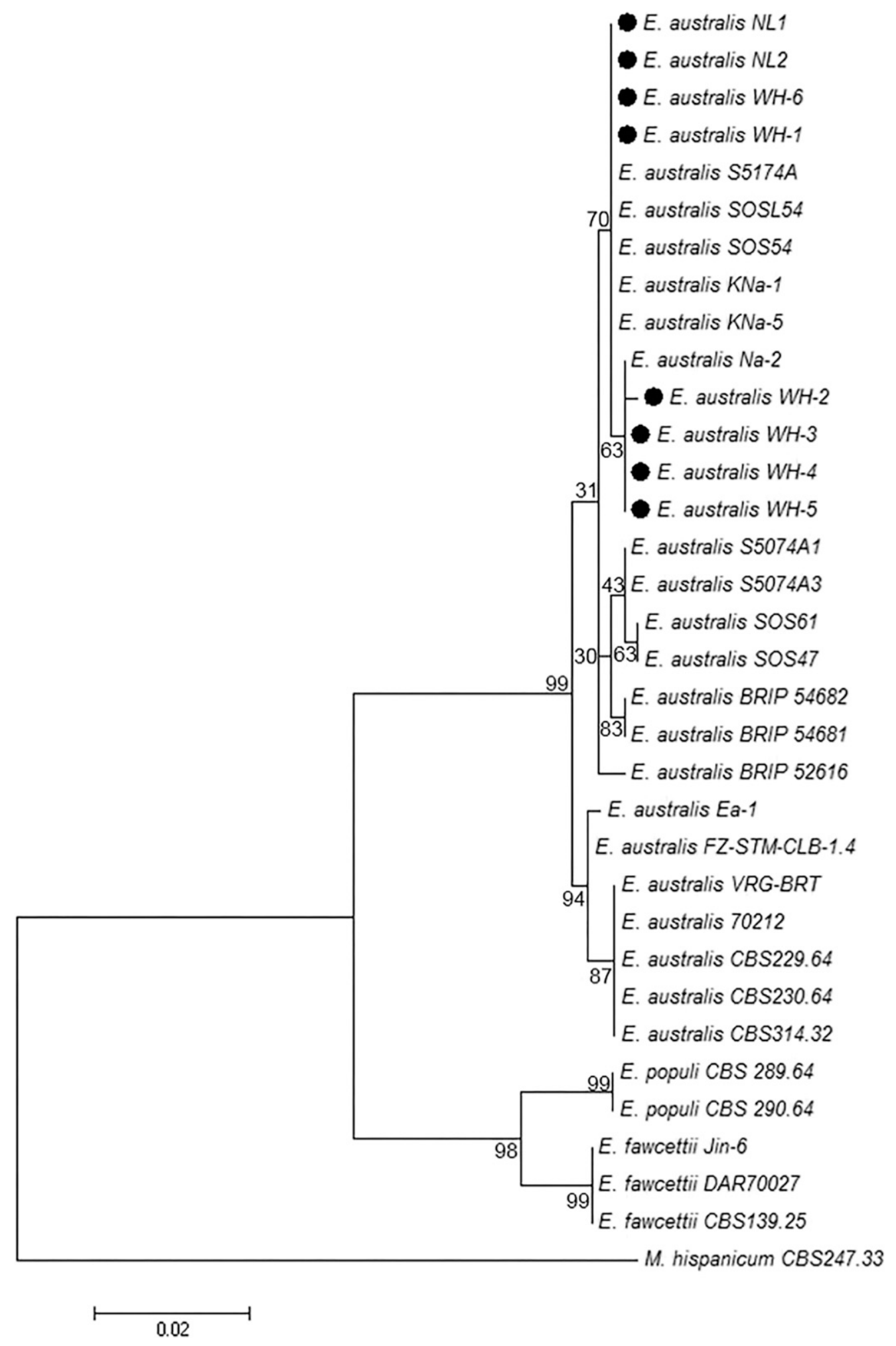

Fig. 2. Molecular phylogeny of Elsinoë spp. in a maximum-likelihood tree based on the alignment of the concatenated internal transcribed spacer and translation elongation factor $1-\alpha$ sequences. Numbers at each node indicate the bootstrap percentage $(n=1,000)$. Black circles indicate the Elsinoë australis isolates recovered in this study. 
In addition, a whole-genome comparison between isolates NL1 and Ea-1 was performed. The generated synteny dot-plot showed the high levels of colinearity between the two genomes (Fig. 4), in which $80.51 \%$ of the NL1 genome sequence can be aligned to the genome of Ea-1.

Characterization of the MAT1 locus. The MAT1-1 locus (accession number MN607981) was revealed using a BLAST search of the E. australis NL1 genome. The homologs of APN2 and MAT1-1-1 were identified and were closely related (Fig. 5A). A hypothetical protein (HP1) gene was located between APN2 and MAT1-1-1, which is the homolog of the MAT1 gene of Aureobasidium pullulans (Gostincar et al. 2014). Downstream of MAT1-1-1 is a phosphoinositide binding domain protein $(P x)$ gene, which was adjacent to the MAT1 locus in A. pullulans. No genes with homology to MAT1-2-1 were identified in the E. australis NL1 genome. Long-range amplification with primers designed to the flanking $A P N 2$ and $P x$ genes revealed the genetic structure of MAT1-2 locus (accession number MN607982) in the WH-2 isolate. Two genes were predicted at the MAT1-2 locus. In addition to the core MAT1-2-1 gene, a hypothetical protein (HP2) gene, which is specific to the Elsinoë spp., was found between the MAT1-2-1 and $P x$ genes (Fig. 5A). Amplification with MAT1-1 idiomorph-specific primer pairs showed that single isolates carry only one of the two opposite idiomorphs (Fig. 5B-C).

\section{Discussion}

In early reports, E. australis was described as a pathogen that only infects sweet orange (C. sinensis) (Bitancourt and Jenkins 1937;
Timmer et al. 1996); however, multiple pathotypes discovered in recent years have greatly expanded the knowledge of the host range of this fungus. To date, it has been reported that the fruit or leaves of Citrus spp., including $C$. natsudaidai, C. paradisi, C. reticulata, and $C$. australasica, are the habitats of E. australis. Furthermore, jojoba (S. chinensis), an oil tree in the order Caryophyllales, is also infected by this fungus, resulting in scab symptoms on leaves (Ash et al. 2012; Hyun et al. 2001, 2009; Kunta et al. 2013; Miles et al. 2015). In this study, we identified the causal agent of spot anthracnose of poplar in China, which represents a new pathotype, PSA, of E. australis. The severity of PSA is low, usually affecting some

Table 2. Summary statistics of the Elsinoë australis NL1 genome assembly

\begin{tabular}{lc}
\hline Attribute & Value \\
\hline Clean data (bp) & $6,080,703,900$ \\
Clean reads & $40,538,026$ \\
Genome size (Mb) & 23.34 \\
DNA scaffolds & 452 \\
GC content (\%) & 52.7 \\
N50 (bp) & 897,805 \\
Largest scaffold (bp) & $1,881,367$ \\
Protein-coding genes & 9,223 \\
Secreted protein genes & 629 \\
CAZymes & 522 \\
\hline
\end{tabular}

a Carbohydrate-active enzymes.
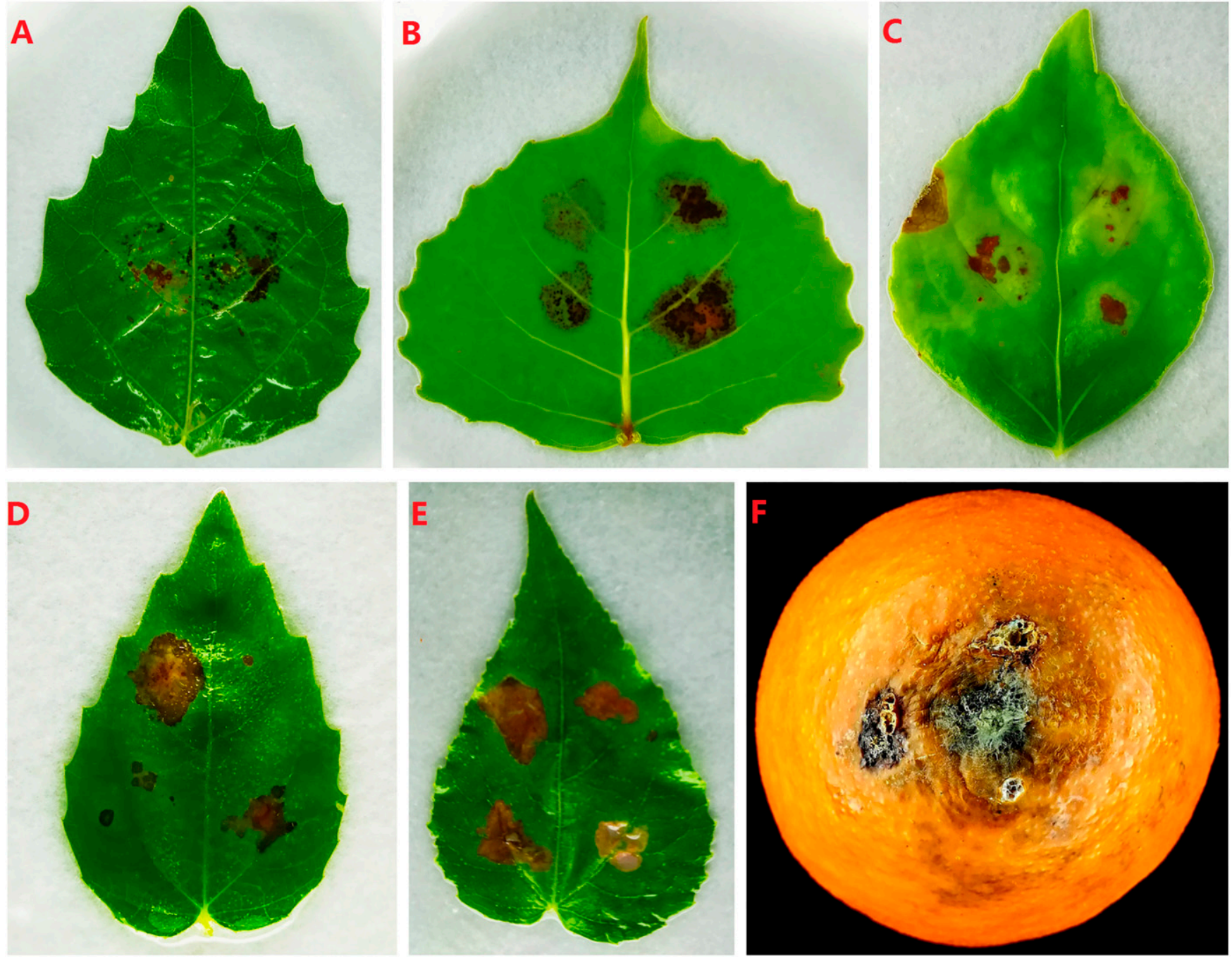

Fig. 3. Symptoms of Elsinoë australis on various hosts. A, Populus tomentosa; B, P. deltoides; C, P. $\times$ euramericana 'Nanlin 895'; D, P. davidiana $\times$ P. bolleana; E, P. tremula $\times$ P. tremuloides 'T89'; and F, Ehime 38 hybrid citrus. 
of the leaves, but this disease is prevalent in poplar. The PSA pathotype could be isolated from distinct sections of poplars from different locations. In addition, in autumn 2019, a brief survey of $P . \times$ euramericana 'Nanlin 895', the primary clone on poplar plantations in the Yangtze-Huaihe River Valley, found a prevalence of distinctive red leaf spots. PCR amplification with idiomorph-specific primers indicated the presence of $E$. australis on these diseased leaves. In China, E. australis has not been identified previously and the SOS pathotype is under quarantine restrictions when importing sweet

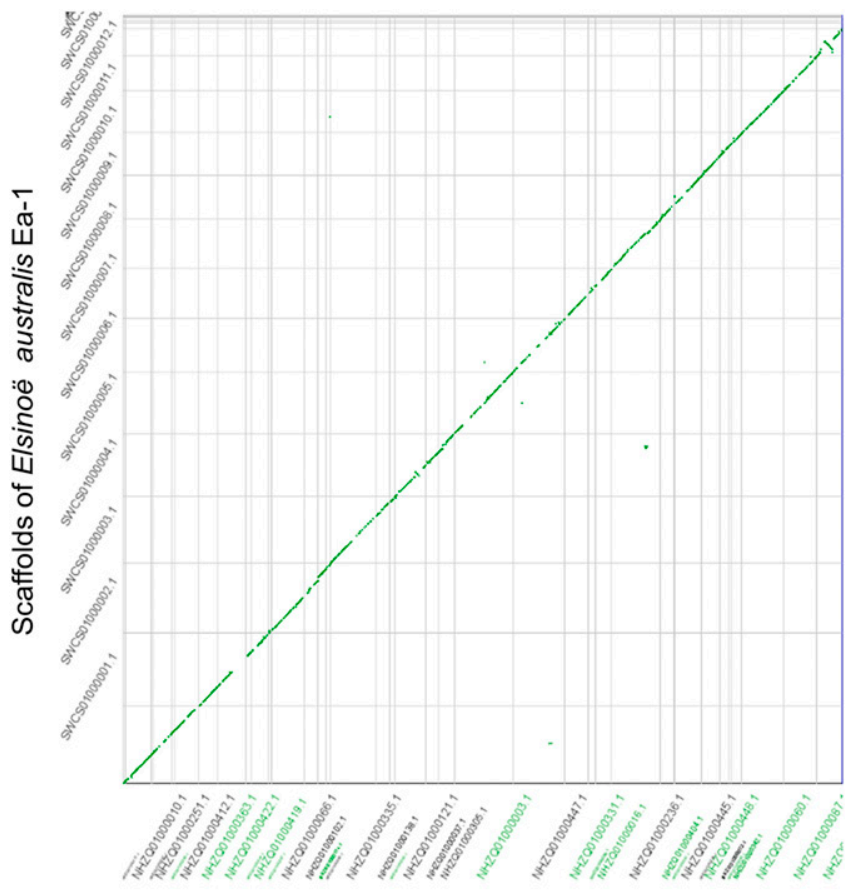

Scaffolds of Elsinoë australis NL1

Fig. 4. Whole-genome dot-plot comparison between isolate NL1 (x-axis) and Ea-1 (y-axis) generated using SynMap. Each dot represents a pair of syntenic region between NL1 and Ea-1. An interactive version of this graphic can be regenerated using the following link: https://genomevolution.org/r/1ayd4 orange. The PSA pathotype also caused scab symptoms under laboratory conditions on the fruit of Ehime 38 hybrid citrus, an important cultivar widely planted in the Sichuan and Jiangxi Provinces of China. Therefore, this PSA pathotype of E. australis could be a potential risk to both poplar and orange plantations.

Sexual reproduction is an important mechanism for fungal pathogens to generate genetic variation so that progeny can colonize new hosts or novel environments. For example, sexual recombinant spores of Phaeosphaeria nodorum make significant contributions to wheat blotch epidemics during a growing season (Sommerhalder et al. 2010), and the clones of wheat-infecting Magnaporthe oryzae, which may have originated through sexual recombination, underwent selection to become specialized to infect particular wheat cultivars in Brazil (Maciel et al. 2014). Although the teleomorph of $E$. australis was found in an initial study in Brazil (Bitancourt and Jenkins 1936), the mating system of $E$. australis is completely unknown. In this study, we investigated the mating loci of E. australis by analyzing genome sequences and long-range PCR. Using PCR with idiomorph-specific primers, we revealed that the eight isolates exclusively carry either the MAT1-1 (five isolates) or MAT1-2 (three isolates) locus, implying a heterothallic system in E. australis. The pathotypes of E. australis with different host ranges were also identified from distinct regions; that is, the SOS, Natsudaidai, Natsudaidai-like, and PSA pathotypes were only discovered in South America, South Korea, Texas, and southeastern China, respectively, and JBS and FL pathotypes only exist in Australia (Miles et al. 2015). Therefore, further research is necessary to monitor the sexual reproduction or gene flow between pathotypes from different hosts and locations.

The ITS and TEF-1 $\alpha$ sequences are usually used for the phylogenetic analysis of E. australis; however, limited polymorphic sites on the two loci among pathotypes are available (Table 1). The isolates of Natsudaidai, Natsudaidai-like, and PSA pathotypes cannot be distinguished by a phylogenetic analysis of combined ITS and TEF-1 $\alpha$ sequences (Fig. 2). In addition, colony morphology and sporulation capacity were variable within PSA and Natsudaidai pathotype isolates (Hyun et al. 2001, 2015). Thus, morphological information on colony and conidia is not likely applicable for characterizing different $E$. australis isolates. Furthermore, owing to sexual compatibility among Citrus spp., the high frequency of bud mutations, and the long history of cultivation, the host materials were confusing and not

A

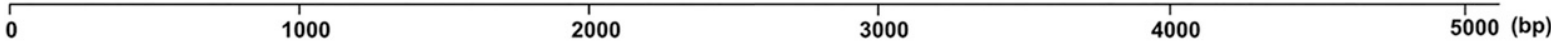

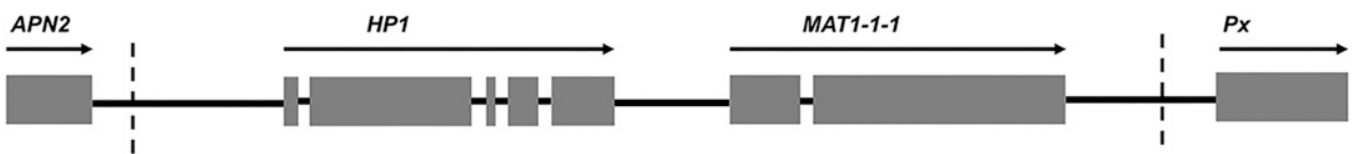

MAT1-2 locus
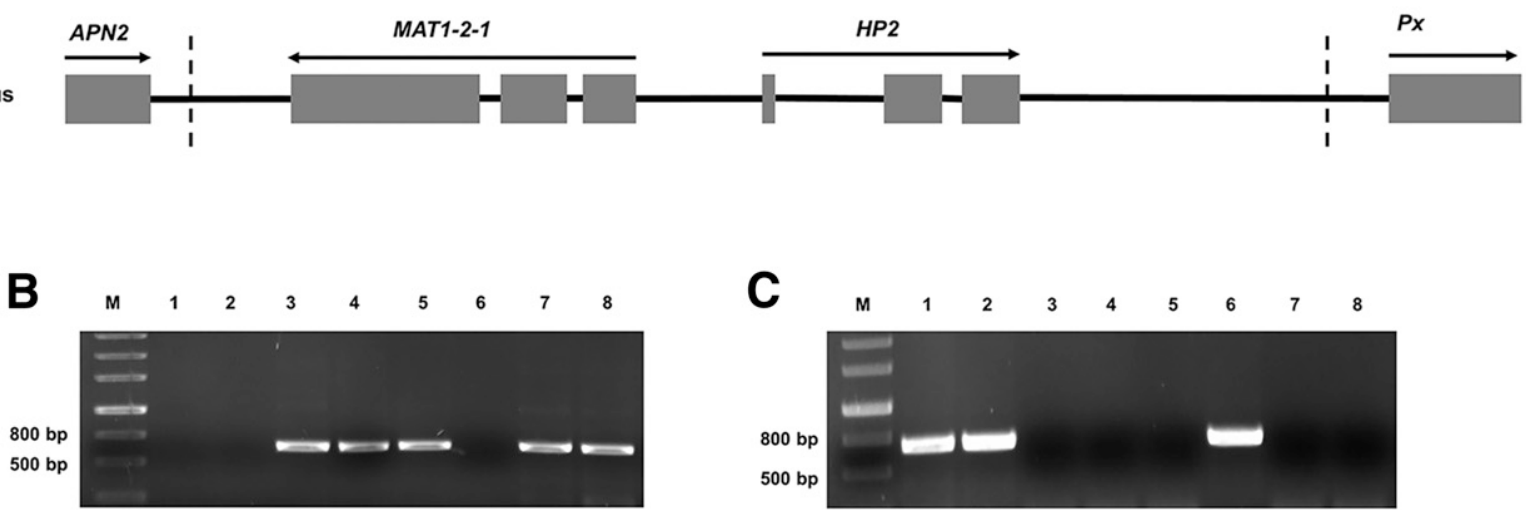

Fig. 5. Mating-type loci and detection of mating types of Elsinoë australis. A, Structures of the MAT1-1 and MAT1-2 loci. Solid boxes represent the coding regions of the predicted genes interrupted by introns. Arrows indicate orientations of coding sequences. Dotted lines label the sizes of the unique sequences of the MAT1-1 idiomorph (3,448 bp) and MAT1-2 idiomorph (3,762 bp). B, Detection of MAT1-1 with idiomorph-specific primers and C, detection of MAT1-2 with idiomorph-specific primers. Lane M = DNA ladder and lanes 1 to $8=$ eight $E$. australis isolates $\mathrm{WH}-1, \mathrm{WH}-2, \mathrm{WH}-3, \mathrm{WH}-4, \mathrm{WH}-5, \mathrm{WH}-6, \mathrm{NL} 1$, and NL2, respectively. 
standardized when establishing different pathotypes. In this study, we provided a genome resource for $E$. australis that could accelerate research on genetic diversity and population structure through the use of multiple loci or molecular markers.

Most recently, one genome of SOS pathotype Ea-1 was reported (Shanmugam et al. 2019). Our preliminary comparison revealed highly similar but distinct genomic contents between NL1 and Ea-1. Furthermore, we also noticed that eight genomic sequences of the JBS pathotype had been submitted to GenBank in 2019. Detailed comparison of genomes of the three pathotypes in the future will provide abundant and polymorphic molecular markers for genetic diversity analyses, and may reveal clues about the mechanisms underlying broad host range adaptation of $E$. australis.

\section{Literature Cited}

Ash, G. J., Stodart, B., and Hyun, J. W. 2012. Black scab of jojoba (Simmondsia chinensis) in Australia caused by a putative new pathotype of Elsinoë australis. Plant Dis. 96:629-634.

Bitancourt, A. A., and Jenkins, A. E. 1936. Perfect stage of the sweet orange fruit scab fungus. Mycologia 28:489-492.

Bitancourt, A. A., and Jenkins, A. E. 1937. Sweet orange scab caused by Elsinö̈ australis. J. Agric. Res. 54:1-18.

Blin, K., Shaw, S., Steinke, K., Villebro, R., Ziemert, N., Lee, S. Y., Medema, M. H., and Weber, T. 2019. antiSMASH 5.0: Updates to the secondary metabolite genome mining pipeline. Nucleic Acids Res. 47:W81-W87.

Bradshaw, H. D., Ceulemans, R., Davis, J., and Stettler, R. 2000. Emerging model systems in plant biology: Poplar(Populus) as a model forest tree. J. Plant Growth Regul. 19:306-313.

Castillo, A. I., Nelson, A. D. L., Haug-Baltzell, A. K., and Lyons, E. 2018. A tutorial of diverse genome analysis tools found in the CoGe web-platform using Plasmodium spp. as a model. Database (Oxford) 2018:bay030.

Chung, K. R. 2011. Elsinoë fawcettii and Elsinoë australis: The fungal pathogens causing citrus scab. Mol. Plant Pathol. 12:123-135.

Cronk, Q. C. B. 2005. Plant eco-devo: The potential of poplar as a model organism. New Phytol. 166:39-48.

Duplessis, S., Major, I., Martin, F., and Séguin, A. 2009. Poplar and pathogen interactions: Insights from Populus genome-wide analyses of resistance and defense gene families and gene expression profiling. Crit. Rev. Plant Sci. 28: 309-334.

Ebert, M. K., Spanner, R. E., Jonge, R. D., Smith, D. J., Holthusen, J., Secor, G. A., Thomma, B., and Bolton, M. D. 2018. Gene cluster conservation identifies melanin and perylenequinone biosynthesis pathways in multiple plant pathogenic fungi. Environ. Microbiol. 21:913-927.

EFSA Panel on Plant Health (PLH), Jeger, M., Bragard, C., Caffier, D., Candresse, T., Chatzivassiliou, E., Dehnen-Schmutz, K., Gilioli, G., Grégoire, J.-C., Miret, J. A. J., MacLeod, A., Navarro, M. N., Niere, B., Parnell, S., Potting, R., Rafoss, T., Urek, G., Van Bruggen, A., Van der Werf, W., West, J., Winter, S., Vicent, A., Vloutoglou, I., Bottex, B., and Rossi, V. 2017. Pest categorisation of Elsinoë fawcettii and E. australis. EFSA J. 15:e05100.

Fan, X. L., Barreto, R. W., Groenewald, J. Z., Bezerra, J. D. P., Pereira, O. L., Cheewangkoon, R., Mostert, L., Tian, C. M., and Crous, P. W. 2017. Phylogeny and taxonomy of the scab and spot anthracnose fungus Elsinoë (Myriangiales, Dothideomycetes). Stud. Mycol. 87:1-41.

Fang, S. Z. 2008. Silviculture of poplar plantation in China: A review. Chin. J. Appl. Ecol. 10:2308-2316.

Gostincar, C., Ohm, R. A., Kogej, T., Sonjak, S., Turk, M., Zajc, J., Zalar, P., Grube, M., Sun, H., Han, J., Sharma, A., Chiniquy, J., Ngan, C. Y., Lipzen, A., Barry, K., Grigoriev, I. V., and Gunde-Cimerman, N. 2014. Genome sequencing of four Aureobasidium pullulans varieties: Biotechnological potential, stress tolerance, and description of new species. BMC Genomics 15:549.

Hyun, J. W., Paudyal, D. P., and Hwang, R. Y. 2015. Improved method to increase conidia production from isolates of different pathotypes of Citrus scab pathogen Elsinö̈ spp. Res. Plant Dis. 21:231-234.

Hyun, J. W., Timmer, L. W., Lee, S. C., Yun, S. H., Ko, S. W., and Kim, K. S. 2001. Pathological characterization and molecular analysis of Elsinö̈ isolates causing scab diseases of Citrus in Jeju Island in Korea. Plant Dis. 85: 1013-1017.

Hyun, J. W., Yi, S. H., Mackenzie, S. J., Timmer, L. W., Kim, K. S., Kang, S. K., Kwon, H. M., and Lim, H. C. 2009. Pathotypes and genetic relationship of worldwide collections of Elsinö̈ spp. causing scab diseases of citrus. Phytopathology 99:721-728.

Jenkins, A. E. 1932. Elsinoë on apple and pear. J. Agric. Res. 44:689-700.

Krogh, A., Larsson, B., von Heijne, G., and Sonnhammer, E. L. L. 2001. Predicting transmembrane protein topology with a hidden Markov model: Application to complete genomes. J. Mol. Biol. 305:567-580.

Kumar, S., Stecher, G., and Tamura, K. 2016. MEGA7: Molecular evolutionary genetics analysis version 7.0 for bigger datasets. Mol. Biol. Evol. 33: $1870-1874$.

Kunta, M., Rascoe, J., Sa, P. B., Timmer, L. W., Palm, M. E., Graça, J. V., Mangan, R. L., Malik, N. S. A., Salas, B., Satpute, A., Sétamou, M., and Skaria, M. 2013. Sweet orange scab with a new scab disease "syndrome" of citrus in the USA associated with Elsinoë australis. Trop. Plant Pathol. 38:203-212.

Luo, R., Liu, B., Xie, Y., Li, Z., Huang, W., Yuan, J., He, G., Chen, Y., Pan, Q., Liu, Y., Tang, J., Wu, G., Zhang, H., Shi, Y., Liu, Y., Yu, C., Wang, B., Lu, Y., Han, C., Cheung, D. W., Yiu, S. M., Peng, S. L., Zhu, X. Q., Liu, G. M., Liao, X. K., Li, Y. R., Yang, H. M., Wang, J., Lam, T. W., and Wang, J. 2012 SOAPdenovo2: An empirically improved memory-efficient short-read de novo assembler. Gigascience 1:2047-217X-1-18.

Maciel, J. L. N., Ceresini, P. C., Castroagudin, V. L., Zala, M., Kema, G. H. J., and McDonald, B. A. 2014. Population structure and pathotype diversity of the wheat blast pathogen Magnaporthe oryzae 25 years after its emergence in Brazil. Phytopathology 104:95-107.

Miles, A. K., Tan, Y. P., Shivas, R. G., and Drenth, A. 2015. Novel pathotypes of Elsinoë australis associated with Citrus australasica and Simmondsia chinensis in Australia. Trop. Plant Pathol. 40:26-34.

Petersen, T. N., Brunak, S., von Heijne, G., and Nielsen, H. 2011. SignalP 4.0: Discriminating signal peptides from transmembrane regions. Nat. Methods 8: 785-786.

Saccardo, P. A. 1878. Fungi Veneti novi vel critici vel mycologiae Venetae addendi, Series VII. Michelia 1:133-221.

Shanmugam, G., Jeon, J., and Hyun, J.-W. 2019. Draft genome sequences of Elsinoë fawcettii and Elsinoë australis causing scab diseases on citrus. Mol. Plant-Microbe Interact. 33:135-137.

Solovyev, V., Kosarev, P., Seledsov, I., and Vorobyev, D. 2006. Automatic annotation of eukaryotic genes, pseudogenes and promoters. Genome. Biol. $7:$ S10.1-12

Sommerhalder, R. J., McDonald, B. A., Mascher, F., and Zhan, J. 2010. Sexual recombinants make a significant contribution to epidemics caused by the wheat pathogen Phaeosphaeria nodorum. Phytopathology 100:855-862.

Tamura, K., and Nei, M. 1993. Estimation of the number of nucleotide substitutions in the control region of mitochondrial DNA in humans and chimpanzees. Mol. Biol. Evol. 10:512-526.

Ter-Hovhannisyan, V., Lomsadze, A., Chernoff, Y. O., and Borodovsky, M. 2008 Gene prediction in novel fungal genomes using an ab initio algorithm with unsupervised training. Genome Res. 18:1979-1990.

Thompson, J. D., Higgins, D. G., and Gibson, T. J. 1994. CLUSTAL W Improving the sensitivity of progressive multiple sequence alignment through sequence weighting, position-specific gap penalties and weight matrix choice. Nucleic Acids Res. 22:4673-4680.

Timmer, L. W., Garnsey, S. M., and Graham, J. H. 2000. Pages 31-32 in Compendium of Citrus Diseases. American Phytopathological Society, St Paul, MN, U.S.A.

Timmer, L. W., Priest, M., Broadbent, P., and Tan, M. K. 1996. Morphological and pathological characterization of species of Elsinoë causing scab disease of citrus. Phytopathology 86:1032-1038.

Waterhouse, R. M., Seppey, M., Simão, F. A., Manni, M., Ioannidis, P. Klioutchnikov, G., Kriventseva, E. V., and Zdobnov, E. M. 2017. BUSCO applications from quality assessments to gene prediction and phylogenomics. Mol. Biol. Evol. 35:543-548

White, T. J., Bruns, T., Lee, S., and Taylor, J. W. 1990. Amplification and direct sequencing of fungal ribosomal RNA genes for phylogenetics. Pages 315-322 in PCR Protocols: A Guide to Methods and Applications. M. A. Innis, D. H Gelfand, J. J. Sninsky, and T. J. White, eds. Academic Press, San Diego, CA, U.S.A

Whiteside, J. O. 1978. Pathogenicity of two biotypes of Elsinoë fawcetti to sweet orange and some other cultivars. Phytopathology 68:1128-1130.

Wilken, P. M., Steenkamp, E. T., Wingfield, M. J., De Beer, Z. W., and Wingfield, B. D. 2017. Which MAT gene? Pezizomycotina (Ascomycota) mating-type gene nomenclature reconsidered. Fungal Biol. Rev. 31:199-211.

Zhang, H., Yohe, T., Huang, L., Entwistle, S., Wu, P., Yang, Z., Busk, P. K., Xu, Y., and Yin, Y. 2018. dbCAN2: A meta server for automated carbohydrateactive enzyme annotation. Nucleic Acids Res. 46:W95-W101. 